\title{
Toward an urban political ecology of energy justice: the case of rooftop solar in Tucson, AZ
}

\author{
Remington Franklin ${ }^{1}$ \\ Tracey Osborne \\ University of Arizona, USA
}

\begin{abstract}
The rapid deployment of rooftop solar panels in many US cities has raised new concerns about the fair distribution of electricity costs through rates. Electric utilities argue that existing rate structures shift costs from solar owners to lower-income ratepayers, while critics say rooftop solar benefits all ratepayers and helps address environmental injustice. In light of these competing justice claims, this article asks: what are the implications of rooftop solar for energy justice? Drawing on a case study from southern Arizona, we use urban political ecology (UPE) to analyze debates about rooftop solar that speak to three types of justice: distributive, procedural, and recognition. While dominant justice claims revolve around the distribution of costs through rates, competing claims emphasize procedural and recognition (in)justice. Focusing on political economy, power relations, and the materiality of the grid, we reframe the utility company's cost shift argument as a strategic narrative and explain why this understanding of justice is recognized as legitimate while others are not. We propose that UPE can further an energy justice analysis by understanding procedural and recognition injustice as systemic products of rate of return regulation, and the material configuration of the electric grid.
\end{abstract}

Keywords: urban political ecology, energy justice, rooftop solar, decentralized energy, electric utility regulation

\section{Résumé}

Le déploiement rapide de l'énergie solaire sur le toit dans de nombreuses villes américaines a suscité de nouvelles inquiétudes quant à la répartition équitable des coûts de l'électricité grâce à des tarrifs. Les entreprises d'approvisionnement en électricité estiment que les structures tarifaires qu'elles utilisent actuellement, déplacent les coûts des propriétaires solaires vers les taux de faible revenu. Mais les critiques disent que l'énergie solaire sur le toit bénéficie à tous les contribuables et contribue à remédier à l'injustice environnementale dans toute la société. À la lumière de ces revendications de justice concurrentes, cet article demande: quelles sont les implications de l'énergie solaire sur le toit pour la justice énergétique? En s'appuyant sur une étude de cas du sud de l'Arizona, États-Unis, nous utilisons «urban political ecology» (UPE) pour analyser les débats sur l'énergie solaire sur le toit qui parlent de trois types de justice: distributive, procédurale et de reconnaissance. Alors que les revendications de la justice dominante tournent autour de la répartition des coûts par le biais de tarrifs, les revendications concurrentes mettent l'accent sur la procédure et la reconnaissance de la (in)justice. En mettant l'accent sur l'économie politique, les relations de pouvoir et la matérialité du réseau électrique, nous révisons l'argument du changement de coût de l'entreprise en tant que récit stratégique. Nous expliquons pourquoi cette compréhension de la justice est reconnue comme légitime,

\footnotetext{
${ }^{1}$ Remington Franklin, MA and Dr. Tracey Osborne, Assistant Professor, School of Geography and Development, University of Arizona, Tucson, Arizona, USA. Emails: remysfranklin "at" gmail.com and tosborne "at" email.arizona.edu. Franklin's research is about the politics of renewable energy transition and social justice in the context of climate change mitigation. Osborne studies the commodification of nature through environmental markets. Acknowledgements: This article represents the collective efforts of a community of practice concerned about energy justice and the urban political ecology of rooftop solar in Tucson, Arizona. We are extremely grateful to research participants who shared their knowledge and insights with us, as well as for their ongoing commitments to creating a more just electricity system in southern Arizona. We thank Miriam Gay-Antaki and Sarah Launius for repeated feedback on early versions of this article, and referees. Our appreciation also goes out to organizers and participants in the American Association of Geographers session on 'Critical geographies of energy infrastructure' where the final version of this research was first presented.
} 
tandis que d'autres ne le sont pas. Nous proposons que l'UPE puisse approfondir une analyse de la justice énergétique, en comprenant l'injustice procédurale et de reconnaissance en tant que produits systémiques de la régulation du «taux de retour» et de la configuration matérielle du réseau électrique.

Mots-clés: écologie politique urbaine, justice énergétique, solaire sur le toit, énergie décentralisée, réglementation des services électriques

\section{Resumen}

El despliegue rápido de energía solar de azotea en muchas ciudades en los Estados Unidos ha presentado nuevas preocupaciones acerca de la distribución justa de los costos de electricidad a través de sus tarifas. Las compañías eléctricas argumentan que las estructuras existentes de tarifas se desplazan de los dueños solares a los clientes de mas bajos ingresos. A la vez, los críticos dicen que la energía solar de azotea beneficia a todos los clientes que pagan y ayuda a resolver la injusticia ambiental. Dado estas declaraciones contradictorias, este articulo pregunta lo siguiente: ¿Cuáles son las implicaciones de la energía solar de azotea para la justicia energética? Basado en un caso de estudio del sur de Arizona, usamos la ecología política urbana (UPE por sus siglas en ingles) para analizar los debates acerca de la energía solar de azotea que hablan de tres tipos de justicia: distributiva, procedimental y de reconocimiento. Mientras los argumentos dominantes de justicia se concentran en la distribución de los costos a través de las tarifas, otros argumentos enfatizan la (in)justicia procedimental y de reconocimiento. Enfocando en la economía política, las relaciones de poder y la materialidad de la red energética, nosotros reorientamos el argumento de las compañías eléctricas sobre el desplazamiento de costos como una narrativa estratégica y explicamos por qué este entendimiento de justicia es reconocido como legitimo mientras otros no lo son. Proponemos que la UPE es útil en un análisis de la justicia energética ya que revela la injusticia procedimental y de reconocimiento como productos sistémicos de una regulación en la taza de rentabilidad y la configuración material de la red eléctrica.

Palabras claves: ecología política urbana, justicia energética, energía solar de azotea, energía decentralizada, regulación de la electricidad

\section{Introduction}

Electric utility rate cases are typically mundane proceedings obscured from the lives of residential consumers. Normally proposed every 2-5 years, rate cases (setting the allowable service charges, or tarrifs, paid by consumers) are a recurring process whereby monopoly investor-owned utilities (IOUs) propose new rates and obtain permission from state regulators. These applications for new rates often last more than a year, playing out in judicial hearings and lengthy exchanges via thousands of pages of technical and legal jargon. But the obscurity of these proceedings belies their relevance to the vast majority of households in the United States, whose electricity rates are directly determined by the outcome.

This article focuses on debates about the proper rate structure for grid-tied decentralized electricity generation (DG) from residential photovoltaic solar panels (PV 'rooftop solar'), as they played out surrounding a rate case filed by the southern Arizona utility company, Tucson Electric Power (TEP), in September 2015. TEP's rate case is just one example of the complex politics surrounding renewable energy transition in many US cities. In light of climate change concerns, solar has emerged as an important opportunity to decarbonize electricity generation, which accounts for $29 \%$ of US greenhouse gas emissions and 68\% of emissions in Pima County where TEP operates (Cotty 2015; EPA 2017). However, there is still no consensus about the optimal scale for solar photovoltaics (centralized power plants or small, decentralized systems) and the socio-economic implications of solar electricity for low-income households.

The geographies of solar infrastructure and its implications for residential utility customers are being decided in highly politicized rate case proceedings, and these have received little attention from critical scholars. These reached a peak in 2016, when 47 US states and DC took 212 solar policy actions related to net metering, rate design, and solar ownership (Proudlove et al. 2017). Arizona saw by far the most actions in 2016, with all three of the state's IOUs requesting changes to solar rate design in cases brought before the state regulators, the Arizona Corporation Commission (ACC). 
Using the TEP rate case as a representative case, this article asks: what are the implications of rooftop solar for energy justice? The discussion begins from a distributive justice claim advanced by TEP and other IOUs: that rooftop solar shifts costs from solar owners onto lower-income ratepayers that cannot afford it. TEP used this cost shift argument to justify new rate structures that recuperate more revenue from solar customers. The changes revolve around a billing mechanism called retail net metering (NEM), which allows customers with onsite generation on their homes to be charged only for their "net" monthly consumption, measured by subtracting the power supplied to the grid from the amount received from the utility company (Lazar 2016). NEM allows rooftop solar owners to offset most of their electric bill, yet they still rely on the grid to exchange electricity throughout the day. The utility says these customers are "not paying an equitable share of the fixed costs to operate and maintain the TEP grid to which they are connected", requiring higher rates for all ratepayers. The latter are assumed to have lower net incomes than solar owners, because they are not home owners or they lack capital or credit to invest in a solar system (TEP 2015). In short, TEP claims that rooftop solar with NEM creates a regressive cross-subsidy that may exacerbate fuel poverty. ${ }^{2}$

Following an ACC decision in December 2016, Arizona became one of the first states to replace NEM with a value of solar (VOS) tariff, which credits DG solar kilowatt-hours at a reduced rate, based on an avoided cost methodology (Jibilian 2017; Pitt and Michaud 2015). State regulators also approved TEP's request to add charges that incentivize residential customers to switch to time-varying billing mechanisms, although at a level significantly below the utility's initial proposal. Collectively, these rate changes added US $\$ 8.50$ to the average residential utility customer's monthly bill and will extend the payback time for new rooftop solar installations in TEP's service territory (Rodda 2017).

While TEP's cost shift argument played a key role in justifying their rate case to state regulators, it was highly contested by rooftop solar advocates. These advocates included representatives and employees of solar installations companies, utility customers, environmentalists, energy choice advocates, and community organizers. Collectively, they argued that rooftop solar provides long-term benefits to all ratepayers by mitigating environmental harm and avoiding the need for costly new grid infrastructure. Ratepayers should be credited adequately for the power they produce. They also claimed that the utility's proposal to increase fixed monthly charges would slow solar deployment and disproportionately burden low-income ratepayers. By advancing competing justice claims, they articulated different understandings of justice - as fair process, and recognition of social and environmental values.

This article uses an urban political ecology (UPE) approach to analyze these competing justice narratives and explain why the utility company's claim was ultimately validated through the TEP rate case. This explanation employs inductive coding of qualitative data, including: 13 semi-structured interviews with utility employees, local government representatives, and rooftop solar advocates; participant observation at four rate case public hearings and related planning meetings, protests, and community events; testimony, reports, and comments filed in the rate case docket kept by the ACC; and consumer comments given at public hearings.

In the following section, we situate the case study within existing literature about energy justice, and discuss how UPE furthers an energy justice analysis. While existing research discusses the implications of rooftop solar for the distribution of costs through rates, our emphasis on political economy, power relations, and the materiality of the grid helps expand the analysis to questions of recognition and procedural (in)justice. In the third section we provide additional historical and topical context for the TEP rate case before analyzing debates about rooftop solar as they relate to three types of justice: distributive, procedural, and recognition. The analysis in sections 4-6 draws on UPE to reframe the utility's cost shift argument as a strategic narrative and reveal why this narrative, rather than competing justice claims, ultimately guided decision-making. We propose that the TEP rate case as a process is unjust, in part because 'rate of return' regulation is structured to

\footnotetext{
${ }^{2}$ Fuel poverty typically refers to households that have to spend over 10 percent of their income on energy services necessary to meet basic needs. Used primarily in a Global North context, fuel poverty is escalating in most countries due to rising fuel prices with decreased household purchasing power (Sovacool, Sidortsov and Jones 2014). We do not offer a specific analysis of fuel poverty in this article, but rather we use the term as a shorthand for the general concern that rising electric rates disproportionately impact low-income utility customers leading to economic stress and reduced quality of life.
} 
disproportionately prioritize shareholder value. However, the unique material properties of rooftop solar create possibilities for greater procedural and recognition justice through wider public participation in electricity governance.

In analyzing the TEP rate case, this article aims to make three contributions. First, we offer a more complete understanding of the implications of rooftop solar for energy justice by considering procedural and recognition justice. We do this by putting energy justice theories into conversation with a narrative analysis of our empirical data taking a UPE approach. Second, we hope to elevate the importance of electric utility regulation and residential solar as sites of contestation over alternative energy futures. These topics have received little attention from energy justice and UPE scholars, but are key arenas through which the geographies of the electric grid are actively being reworked. Finally, we hope to demonstrate how UPE offers a useful lens for analyzing energy justice, in particular by understanding procedural and recognition injustice as systemic products of rate of return regulation and the material configuration of the electric grid.

\section{Toward an urban political ecology of energy justice}

A recent conceptual review summarizes energy justice as the application of justice principles to "energy policy, energy production and systems, energy consumption, energy activism, energy security, the energy trilemma, political economy of energy and climate change" (Jenkins et al. 2016: 175). Understood in this broad sense, energy justice encompasses concerns addressed in related literature on environmental justice (Schlosberg 2004, 2013; Walker 2009), climate justice (Barrett 2013; Burnham et al. 2013; Forsyth 2014; Bond 2015), fuel poverty (Walker 2008; Sovacool, Sidortsov and Jones 2014), energy geographies (Bridge et al. 2013; Calvert 2015; Huber 2015), and political ecologies of climate change (Tschakert 2012; Liverman 2015). Sovacool and Dworkin (2015: 441) offer a positive definition:

We define an energy just world as one that equitably shares both the benefits and burdens involved in the production and consumption of energy services, as well as one that is fair in how it treats people and communities in energy decision-making.

This definition captures important components of the conceptual understanding of energy justice that we draw on in this article. Energy produces benefits and burdens, through its consumption and production, and justice requires not only the fair distribution of these costs and benefits, but also justice in the decisionmaking processes that determine that distribution. Implicit in this definition is the crucial but often overlooked question of which people or values are recognized when evaluating justice as distribution and process (Young 1990; Fraser 1997; Schlosberg 2004).

We therefore follow an analytical distinction between three types of justice: distributive, procedural, and recognition (Table 1). This approach draws on foundational justice theories developed by political philosophers such as Rawls (1971), Young (1990), Fraser (1997), and Fainstein (2010), and more recently applied to energy (Bickerstaff, Walker and Bulkeley 2013; McCauley et al. 2013; Fuller and Mccauley 2016; Jenkins et al. 2016; Sovacool and Dworkin 2015; Sovacool, Sidortsov and Jones 2014). This trivalent conceptualization is useful both for evaluating energy (in)justice and for guiding normative questions (Jenkins et al. 2016):

- How should we redistribute costs/benefits?

- Which processes achieve more just outcomes?

- How/whom should we recognize? 


\begin{tabular}{|l|l|l|}
\hline Tenet & \multicolumn{2}{|l|}{ Positive definition } \\
\hline Distributive & $\begin{array}{l}\text { Fair distribution of social } \\
\text { goods and harms related } \\
\text { to energy production and } \\
\text { consumption. }\end{array}$ & $\begin{array}{l}\text { What goods are distributed? Between what entities? What is } \\
\text { the proper mode of distribution (e.g. need, merit, utility, } \\
\text { entitlement, property rights)? (Sovacool and Dworkin 2015). }\end{array}$ \\
\hline Procedural & $\begin{array}{l}\text { Equitable access to } \\
\text { participation in decision- } \\
\text { making processes that } \\
\text { govern distributions. }\end{array}$ & $\begin{array}{l}\text { Three mechanisms of inclusion to achieve just outcomes: } \\
\text { local knowledge mobilization, greater information } \\
\text { disclosure, better institutional representation (Jenkins et al. } \\
\text { 2016). }\end{array}$ \\
\hline Recognition & $\begin{array}{l}\text { Fair representation, equal } \\
\text { political rights, and } \\
\text { freedom from physical } \\
\text { threats. }\end{array}$ & $\begin{array}{l}\text { Who and what forms of knowledge are afforded recognition } \\
\text { in process? What are the social, cultural, symbolic, and } \\
\text { institutional conditions underlying poor distributions? Three } \\
\text { main categories of misrecognition: cultural domination, non- } \\
\text { recognition, and disrespect (Fraser 1997; Schlosberg 2004). }\end{array}$ \\
\hline
\end{tabular}

Table 1: Three tenets of energy justice.

Existing research about rooftop solar is limited to questions of distributive justice, and critical social scientists have been surprisingly silent on justice questions surrounding decentralized generation. For example, economic, policy, and technical analyses discuss rooftop solar and justice only in the narrow sense of how electricity costs are distributed through rates (Darghouth et al. 2016; Eid et al. 2014; Procter 2014; Pitt and Michaud 2015; Yamamoto 2012). The opposite is true of critical social science, which takes a more nuanced approach to justice but has barely discussed DG. Rooftop solar receives only a brief mention in an edited volume on energy justice and low-carbon transition (Bickerstaff, Walker and Bulkeley 2013), where the authors cite reports suggesting that feed-in tariffs may exacerbate fuel poverty in the UK (Stockton and Campbell 2011; Preston et al. 2013). Walker (2008) offers a speculative review of links between DG and fuel poverty, cautioning that a development model focused on individuals paying for and installing technologies could lead to lower-income households becoming even more of an energy underclass. However, DG could also resolve fuel poverty if local governments, housing associations, and energy suppliers actively provide pathways for low-income households to benefit. While not based on empirical research, Walker (2008) makes the important point that the justice impacts of rooftop solar are contingent on the existence or absence of programs to support low-income participation.

Oppenheim (2016) makes an important contribution by discussing how utility regulation in the US might evolve to address carbon reduction goals and fuel poverty. However, Oppenheim takes the cost shift argument as given, saying that DG solar threatens to exacerbate fuel poverty by reducing utility sales but not fixed costs, thus contributing to higher bills for low-income households that cannot afford to invest in rooftop solar. The problem is that these existing assessments limit their focus to the distributive implications of rooftop solar for fuel poverty. While this is an important focus, it offers no insight about procedural and recognition justice, nor of the competing justice claims put forward by solar advocates in the TEP rate case.

Existing research on rooftop solar does not generally consider the role of political and economic power in shaping and framing energy justice claims. This article presents empirical research that helps fill this gap by drawing on urban political ecology. Following in the tradition of historical-materialist radical geographies, UPE aims to expose the processes that produce inequality in urban environments (Swyngedouw and Heynen 2003). These are produced by historically specific capitalist forms of the social organization of nature's metabolism. Here, metabolism is used as a metaphor for a relational approach to urbanization that casts urban processes as globally connected through vast networks of socio-material flows that incorporate human and non-human actants, from capital to wires, electrons, and communication on energy policy (Heynen, Kaika 
and Swyngedouw 2006; Silver 2016). UPE invites us to trace these flows to draw connections between global political economy and urban change.

UPE scholars often take urban infrastructure as a starting point for analysis, recognizing that infrastructure networks act as conduits and sites for processes of socio-natural transformation (Heynen, Kaika and Swyngedouw 2006). UPE understands the urban electric grid as a produced socio-natural entity, which by enabling other metabolic flows is fundamentally enrolled in shaping and mediating urbanization. This approach reveals how the geographies of the electric grid reflect and reinforce configurations of political power (Silver 2016). Using material infrastructure as an entry point allows us to consider the implications of different network configurations for the (re)production of inequality in the city.

As an analytical and epistemological approach, UPE is fundamentally concerned with justice. By recognizing that the material conditions of urban environments are historically specific, UPE focuses on the ways processes of urban change have been largely controlled and manipulated to serve the interests of the elite at the expense of marginalized populations (Swyngedouw and Heynen 2003). Critique of the uneven social production of urban environments is usually coupled with an explicitly normative approach. The political program of UPE is therefore to "enhance the democratic content of socioenvironmental construction by identifying strategies through which a more equitable distribution of social power and a more inclusive mode of environmental production can be achieved" (Swyngedouw and Heynen, 2003: 898).

While UPE offers a useful framework for understanding urban infrastructure, it has only recently been applied to thinking about electricity specifically. UPE was developed around studies of water (Swyngedouw 1996; Kaika 2006; Loftus 2006), while work on energy infrastructure is less common (notable exceptions include Broto and Bulkeley 2013, and Luque-Ayala and Silver 2016). ${ }^{3}$ Electricity plays as fundamental a role as water in shaping urbanization processes, and in US cities access to energy is now a precondition for social, political, and economic equality (Sovacool, Sidortsov and Jones 2014). Considering electricity's unique material properties and central role in enabling urban life, it seems important to develop a differentiated UPE of the electric grid. Progress has recently been made in an edited volume that draws on UPE to synthesize conceptual approaches to the politics of the urban grid, proposing three foci: uneven geographies, processes of rewiring the grid, and social movements and protest (Luque-Ayala and Silver 2016). Others explain how UPE sheds theoretical light on energy transitions by emphasizing institutional change, materiality, power, and space (Gailing and Moss 2016).

This article contributes to this emerging literature with analysis of an under-studied context: rooftop solar and electric utility ratemaking in the US. Urban political ecology analysis centers our analysis on the role of political economy and materiality in shaping energy governance, and in rooftop solar and energy justice. By taking a relational approach to the urban, we attempt to operationalize a "whole energy systems" approach that acknowledges multiple dimensions of justice at sites of energy production and consumption (Jenkins et al. 2016).

\section{The TEP rate case in context}

Electric power in Tucson has always been contested. The company now called Tucson Electric Power began operations in 1892, when electrification was just reaching North American cities. Tucson signed its first 25-year franchise agreement with TEP in 1901, and this arrangement is still in place with the most recent franchise renewal in 2000. When Arizona became a US state in 1912, the Arizona Corporation Commission began regulating rates and overseeing the state's utilities. In contrast to most states where utility regulators are appointed by the governor, the ACC, with its five elected commissioners, is the state's fourth branch of government. Constitution drafters decided to elect commissioners in response to fears that governors would appoint industry-friendly officials. As soon as the ACC was established, the City of Tucson (hereafter

\footnotetext{
${ }^{3}$ A frequency count of key terms in UPE review articles shows that water is discussed much more than energy or electricity in this literature. In frequently cited UPE review articles (Swyngedouw and Heynen 2003; Keil 2005; Heynen, Kaika and Swyngedouw 2006; Zimmer 2010; Heynen 2014), "water" appears many more times (n=15, 809, 14, 11, 29 respectively) than "electricity" ( $n=0,43,0,1,1)$ and "energy" (n=0, 32, 3, 1, 3).
} 
"Tucson") filed a complaint that the company discriminated by charging some customers more than others and arguing that a 50 cent monthly meter charges was "excessive and unreasonable" (TEP 2016c).

TEP filed its first rate case with the ACC in 1961, requesting a rate increase of $12 \%$, eventually approved at 10.5\% after three days of hearings (TEP 2016c). Aside from the length of present-day hearings (the current rate case has lasted 682 days at the time of writing), the basic structure of TEP's relationship with the ACC and Tucson has not changed. As an investor-owned utility company, TEP is still a monopoly public service company regulated by the ACC to ensure "just and reasonable" rates for consumers and a "reasonable" rate of return for shareholders (ACC 2014). What is just and reasonable has always been debated with the ACC as the final arbiter between shareholder and ratepayer interest. TEP has therefore occupied a remarkably similar political and economic position for the past century: it is regulated by the ACC, is responsible to extra-local shareholders, and maintains a franchise relationship with Tucson. Furthermore, concerns about regulatory capture are still salient, and rates continue to be contested.

In recent history, decentralized generation and renewables have posed new challenges for IOUs like TEP. While conflicts between small-scale solar and the US utility industry date back to at least the 1970s, levels of DG integration were initially very low. This has changed since 2000 as a result of rapid growth of DG solar due to three main factors: photovoltaic cost declines and rising average retail electricity prices; federal and state tax incentives; and substantial investment by finance and technology industries in part through third-party ownership models (Hess 2016). At higher levels of deployment, DG reduces utility revenues and threatens the utility's business model by disrupting their monopoly on retail electricity sales (Oppenheim 2016). Since 2013, utilities have responded with a variety of strategies via legislatures, courts, and markets (Hess 2016).

Arizona's three IOUs have played a central role in the industry's response to rooftop solar over the past five years with TEP and UniSource Energy Services (UES) often following the state's largest supplier, Arizona Public Service (APS). In 2012, APS became one of the first to propose rate changes designed to recover lost revenues from solar customers via a US\$50-100 monthly standby charge (Blackburn, Magee and Rai 2013). While approved by the ACC at a much lower level, APS's proposal sparked contentious politics that played out through additional rate proposals, re-interpretations of property tax laws, and claims of undue utility influence over regulators (Hess 2016). While APS initiated one of the first attempts to undermine rooftop solar, the state's IOUs are also viewed as industry leaders in renewable energy. In 2014 and 2015, APS and TEP became the first IOUs in the nation to offer utility-owned rooftop solar programs to their customers. TEP has also committed to sourcing $30 \%$ of its electricity generation from renewables by 2030 , going beyond the Arizona's requirement of 15\% by 2025 (TEP 2016a). This paradoxical image underscores the tendency, as one interviewee put it, for Arizona's utilities to embrace solar "as long as they own it" (201605-25). ${ }^{4}$

TEP and APS's response to rooftop solar makes sense in the historical context of the regulatory compact that has structured the electric power industry for the past century. Founded partly on a consensus that marketplace economics ignored social justice - including universal service goals - the regulatory compact offers "just and reasonable rates" in exchange for investor security, or a guaranteed ability to earn a "reasonable" return on investments in the public interest (Oppenheim 2016). The regulatory compact relies on rate of return regulation, which rewards utilities for generating and selling increasing quantities of electricity (Lazar 2016). However, US electricity sales have declined most years since 2007 (EIA 2016). This business model therefore faces unprecedented challenges from energy efficiency, third-party disintermediation of demand-side energy solutions, and DG most of all (Blackburn, Magee and Rai 2013).

This context informed TEP's June 2015 request to reform retail net metering (NEM), which the ACC delayed to a full rate case filed in September. In the rate case, TEP proposed three changes with direct implications for rooftop solar and energy justice (summarized in Table 2): replace NEM with a 'value of solar' tariff (see Section 1), increase the monthly basic service charge, and add a new demand charge based on a customer's peak monthly usage (TEP 2015). Debates about NEM reform were particularly contested. TEP

${ }^{4}$ Informants are either not named or called by a pseudonym to respect anonymity. Personal communication is cited in-text by date (YYYY-MM-DD). 
announced its decision to reform NEM without approval from the ACC and included a June 2015 grandfathering date for existing customers. This created challenges for solar installers who could no longer estimate payback times in the absence of guarantees about the new rate structure (2016-05-25). In response to the proposal to reform NEM, Solar City (a national installation company with 70\% of Tucson's market share) spent US\$3 million backing a Political Action Committee that launched a ballot initiative to entrench NEM in the Arizona constitution (Trabish 2016). As momentum for the ballot initiative built in early 2016, conservative legislatures introduced a competing ballot initiative, and both efforts collapsed after reaching a settlement behind closed doors. These dueling ballot initiatives reveal the highly politicized nature of the NEM debate, which took place through and beyond the TEP rate case.

\begin{tabular}{|l|l|l|}
\hline Item & Initial proposal & Outcome \\
\hline $\begin{array}{l}\text { Retail net } \\
\text { metering (NEM) }\end{array}$ & $\begin{array}{l}\text { Discontinue NEM (excess DG solar } \\
\text { compensated at retail rate of } \\
\text { US\$0.115/kWh) and compensate } \\
\text { new DG customers at a Renewable } \\
\text { Credit Rate of US\$0.058/kWh. }\end{array}$ & $\begin{array}{l}\text { Replace NEM with a value of solar tariff based on } \\
\text { an avoided-cost methodology, with the exact } \\
\text { credit decided in Phase 2 of the rate case (the } \\
\text { exact amount was undecided at the time of } \\
\text { writing, but per the utility's latest proposal is } \\
\text { likely to be US\$0.097/kWh). }\end{array}$ \\
\hline $\begin{array}{l}\text { NEM } \\
\text { grandfathering }\end{array}$ & $\begin{array}{l}\text { Customers with solar prior to June 1, } \\
\text { 2015 retain NEM for 20 years. }\end{array}$ & $\begin{array}{l}\text { Customers with solar (or who have filed a request } \\
\text { to interconnect a new DG solar system) by the } \\
\text { date when new solar rates are approved (likely } \\
\text { late-2017) retain NEM for 20 years. }\end{array}$ \\
\hline $\begin{array}{l}\text { Basic service } \\
\text { charge (BSC) }\end{array}$ & $\begin{array}{l}\text { Increase from US\$10 to } \\
\text { US\$20/month for all residential } \\
\text { customers. }\end{array}$ & $\begin{array}{l}\text { Increase to US\$13/month with optional } \\
\text { US\$10/month for customers that adopt three-part } \\
\text { rate design. }\end{array}$ \\
\hline $\begin{array}{l}\text { Residential rate } \\
\text { design }\end{array}$ & $\begin{array}{l}\text { (BSC + volumetric charge) to three- } \\
\text { part rates (+ demand charge based } \\
\text { on highest hourly energy use) for } \\
\text { new DG users. }\end{array}$ & $\begin{array}{l}\text { DG and non-DG customers choose between two- } \\
\text { part plan (with US\$13/month BSC) or new three- } \\
\text { part plans, including time-of-use and peak } \\
\text { demand options (retain US\$10/month BSC). }\end{array}$ \\
\hline $\begin{array}{l}\text { Estimated bill } \\
\text { impact }\end{array}$ & $\begin{array}{l}\text { US\$11.91/month increase for } \\
\text { average residential customer. }\end{array}$ & $\begin{array}{l}\text { US\$8.50/month increase for average residential } \\
\text { customer. }\end{array}$ \\
\hline
\end{tabular}

Table 2: Select TEP rate case proposals and outcomes relevant to residential rooftop solar.

As with previous rate cases, the purpose of TEP's application was to establish "just and reasonable rates and charges designed to realize a reasonable rate of return on the fair value of the properties of Tucson Electric Power Company" (TEP 2015). The rate case followed a well-established regulatory process (Lazar 2016) lasting over 18 months, in which an administrative law judge (ALJ) was appointed to oversee the case and make a recommendation to the ACC, which would ultimately vote to approve, amend, or reject the ALJ's proposal. Twenty-seven parties intervened in the rate case, including other AZ utility companies, local government, companies and institutions that buy electricity from TEP, solar industry groups, and non-profit advocates. ${ }^{5}$ Intervening parties were given a seat at the negotiating table and the opportunity to provide

\footnotetext{
${ }^{5}$ Intervening parties included corporations and utilities (Freeport Minerals Corporation; Nobles America Energy Solutions; Arizona Investment Council; Arizona Public Service Company; Kroger; Wal-Mart Stores, Inc. and Sam's West, Inc.; Tucson Meadows; SOLON Corporation), non-profit organizations (Arizona Utility Ratepayer Alliance; Vote Solar; The Sierra Club's Arizona members; Energy Freedom Coalition of America; Arizona Solar Energy Industries Association; The Alliance for Solar Choice; Western Resource Advocates; Arizona Community Action Association; Southwest Energy Efficiency Project; Southern Arizona Home Builders Association; Arizona Solar Deployment Alliance; Arizona
} 
official testimony. Consumers filed public comments online or in a public hearing where they spoke directly to commissioners. Testimony and comments were synthesized by the ALJ in a Recommended Order and Opinion (ROO), which the Commission ultimately approved with amendments (Rodda 2017).

The TEP rate case went through several of these cycles, with various ROOs and rounds of voting addressing different components of the utility company's application (Table 2). In August 2016 the case was split into two parts; a decision on NEM was deferred until Phase 2, after the conclusion of a separate but ongoing Value of Solar proceeding. The VOS proceeding concluded in December 2016 with a decision to replace NEM with a VOS tariff based on an avoided-cost methodology, with exact calculations left to individual utility rate cases (Jibilian 2017). In February 2016, Phase 1 resolved non-NEM rate design questions by increasing the basic service charge from US\$10 to US\$13 for all customers, and creating an option for customer to keep the US\$10 monthly charge if they adopt time-of-use rates or demand billing (Rodda 2017). These changes were expected to add an average of US $\$ 8.50$ to residential customers' bills, compared to US\$12 under the utility's initial proposal (Wichner 2015, 2016a). The exact credit of TEP's VOS tariff has not been decided at the time of writing, but based on the latest proposal is likely to be US $\$ 0.097 / \mathrm{kWh}$, compared to US\$0.115 previously (Walton 2017).

While TEP's new rates will extend the pay-back period for rooftop solar customers and increase bills for all ratepayers, they represent only a partial victory for the utility company. In this sense, they follow a predictable pattern of compromise between the company's proposal and ratepayer interests in lower electricity rates and more solar (Elias et al. 2013). The rate of return on equity was approved at $9.35 \%$, below the company's initial request for $10.35 \%$ (Rodda 2017). Similarly, vocal consumer and industry opposition to increasing basic service charges and adding demand charges likely influenced the Commission's decision to make demand charges optional and to approve a basic service charge much lower (US\$13) than the initial TEC proposal of US\$20/month (Rodda 2017). These outcomes suggest that TEP and the ACC did respond to consumer sentiments, especially concerns about fuel poverty. Not only did the ACC strike a compromise, but TEC increased bill supports and lowered the eligibility threshold for their low-income Lifeline program (TEP 2017). TEP also initiated a pilot program to install 1,000 smart Nest thermostats in low-income ratepayer residences (TEP 2016b). However, the decision to remove NEM is expected to "devastate the [rooftop solar] industry in Arizona" (Wichner 2016b). In the following section, we trace the justice claims mobilized to support and contest these outcomes, and analyze what they reveal about the implications of rooftop solar for energy justice.

\section{Rooftop solar and narratives of justice}

It's marketing. It's just a stupid, baseless, political argument. The rates are manipulated. The Diamondbacks and the Cardinals pay a different rate than commercial. The industrial mines pay a different rate. I can't remember how many different rates there are for certain customers, based upon value judgements. - Candidate in the ACC election (2016-08-16)

This section presents results from a narrative analysis of debates about rooftop solar, drawing on interviews, participant observation, documents, and public comments in the TEP rate case. Political ecologists often use narrative analysis to question how environmental and scientific explanations are constructed and to whose benefit (Bixler 2013; Nijbroek 2014). Narratives can only be understood in relation to a broader social context. We therefore draw on urban political ecology to analyze how power, political economy, and the materiality of infrastructure relate to three co-constitutive types of (in)justice: distributive, procedural, and recognition (summary in Table 3).

Competitive Power Alliance), unions (The International Brotherhood of Electrical Workers, Local Union 1116), government entities (Pima County, the Arizona Residential Utility Consumers Office RUCO, The United States Department of Defense and all other Federal Executive Agencies), and individual residential customers. 


\section{Distributive justice: the cost shift narrative}

In the context of energy, distributive justice requires the fair distribution of social goods and harms related to energy production or consumption (Sovacool and Dworkin 2015). TEP's cost shift argument is a distributive justice narrative. The utility claims that retail net metering allows solar customers to avoid paying their fair share of the fixed costs to maintain the grid they rely on, which creates a regressive cross-subsidy from higher- to lower-income ratepayers (TEP 2015). The utility's proposal is premised on the claim that these new rate structures will more fairly distribute the costs of providing electricity services among customers.

\begin{tabular}{|c|c|c|}
\hline Justice tenet & Narratives in TEP rate case & Analysis: implications of residential rooftop solar \\
\hline Distributive & $\begin{array}{l}\text { Rooftop solar shifts costs from } \\
\text { higher- to lower-income } \\
\text { ratepayers; solar benefits all } \\
\text { ratepayers through avoided grid } \\
\text { and environmental/social costs, } \\
\text { and economic development; } \\
\text { utility cost shift narrative is } \\
\text { subjective and contingent. }\end{array}$ & $\begin{array}{l}\text { Distributive implications depend on processes that are } \\
\text { highly contested (i.e. TEP rate case, VOS proceeding, } \\
\text { ACC election). Implications for fuel poverty depend on } \\
\text { presence/absence of initiatives to make DG solar } \\
\text { accessible to low-income ratepayers. TEP's claim that } \\
\text { NEM creates a regressive cross-subsidy was made true } \\
\text { through the ACC's decision to grant the rate increase } \\
\text { justified by this claim. }\end{array}$ \\
\hline Procedural & $\begin{array}{l}\text { Rate case and utility regulation } \\
\text { are unjust because shareholder } \\
\text { interests are prioritized; rooftop } \\
\text { solar promotes public } \\
\text { participation in electricity } \\
\text { governance, creating } \\
\text { possibilities for greater } \\
\text { procedural justice. }\end{array}$ & $\begin{array}{l}\text { Processes deciding distribution are unjust. TEP rate case } \\
\text { begins with proposals promoted by utility and fossil fuel } \\
\text { industry interests (e.g. ALEC model legislation), and } \\
\text { political-economic structure of utility relationship with } \\
\text { state/local government gives shareholder values } \\
\text { disproportionate influence (e.g. municipal franchise tax, } \\
\text { regulatory capture). Rooftop solar is assembling publics } \\
\text { participating in electricity governance for the first time, } \\
\text { but implications for justice require further research. }\end{array}$ \\
\hline Recognition & $\begin{array}{l}\text { VOS should recognize } \\
\text { externalized costs and benefits; } \\
\text { public participation by rooftop } \\
\text { solar advocates promotes } \\
\text { greater recognition of utility } \\
\text { customer values and interests. }\end{array}$ & $\begin{array}{l}\text { Rate of return regulation leads to systematic non- } \\
\text { recognition of values that are not shareholder value. This } \\
\text { led to a rate case process and VOS decision that devalued } \\
\text { justice claims by rooftop solar advocates and validated } \\
\text { the utility's cost shift narrative. }\end{array}$ \\
\hline
\end{tabular}

Table 3: Analysis summary: the implications of rooftop solar for energy justice in Tucson, AZ

This cost shift narrative played a central role in justifying TEP's rate case to state regulators, local government, utility customers, and other stakeholders. In the spring of 2015, TEP's CEO Dave Hutchins convened a meeting with the Tucson Mayor's Office to inform the City of their upcoming rate case. Their justification was catered to a mayor who is known to extol the benefits of solar at industry events:

Under the current rate regime there's a lot of uncertainty, which is not good for investment and creates a barrier for us moving quickly into a clean economy. The new rates will give us more certainty in our revenue, allowing us to plan better and move away from dirty generation to clean generation. (2016-06-10)

That is how Brian Cohen, a policy advisor to the mayor, recalls the explanation provided by a TEP representative. He remembers that TEP was also concerned about a cost shift from high- to low-income customers: 
They said, "look we have a real cost shift from high- to low-income folks, because it's middleand higher- income folks that put solar on their roof. They're the customers that usually buy more of our product, so we get more revenue from them. But when they migrate off the grid, we lose that customer base, and then they want us to pay them retail rate for power they push back onto it. Not only do we lose revenue by losing them as customers, we lose revenue because we now have to pay them for this generation. And who's left on the grid? The lowerincome folks. So then they have to pay for more of our investments in terms of infrastructure." So that was one of their arguments, which was like, oh that doesn't sound too good. (2016-0610)

Cohen recalls that TEP likened the DG solar cost shift to the City's rainwater harvesting initiative. That program is funded through a conservation fee on each customer's bill, which provides incentives for residential and small commercial customers to install rain gardens and harvesting tanks. However, the City realized that higher-income households disproportionately take advantage of the rebate. In an interview, Cohen pointed to a map of rainwater harvesting systems installed through the program, noting clusters in the wealthier Catalina Foothills north of Tucson. "We're all paying for it, but only wealthy people are using it," he explained. "When TEP came and said retail net metering is like your rainwater cistern program, we got it."

Tucson Electric Power's interactions with the City exemplify how the utility's cost shift narrative played a central role in justifying TEP's rate case to local government and state regulators. This narrative was ultimately put into practice through TEP's rate case and the state-wide Value of Solar proceeding, which ruled that the value of DG solar should be based on an avoided cost methodology using a five-year timeframe that does not incorporate societal or economic benefits (Jibilian 2017). In validating the utility's narrative, this decision ignored the "full long-term benefit and cost analysis" rooftop solar advocates repeatedly called for to support their claim that solar benefits all ratepayers (Jibilian 2017).

Rooftop solar advocates contested TEP's cost shift narrative most explicitly by arguing that the methodology for calculating the value of DG solar should incorporate a wider range of costs and benefits over a longer timeframe. Advocates often articulated this claim as environmental injustice, noting how electricity generated to service Tucson produces externalities that affect distant sites and bodies. As a local physician testified at the TEP rate case hearing:

Coal, in fact, has significant health impacts, specifically for those people who work in the mining of coal and the production of fuel for the power plants and who live around the power plants, and that's including the Navajo Nation.... Clean, safe renewable energy has none of these impacts. (2016-08-31)

TEP's 7.5\% ownership of the coal-fired Navajo Generating Station was a repeated reference-point for solar advocates claiming that the value of solar should incorporate mitigated costs to marginalized populations, future generations, and the environment. These claims were echoed by industry groups like The Alliance for Solar Choice, which referenced studies calculating the value of DG solar as high as US\$0.237 (compare to TEP's US $\$ 0.115$ retail rate) based on a methodology that incorporates environmental, economic development, and grid security benefits (Jibilian 2017). This matching of methodology with interests is consistent with VOS debates in other states, where studies commissioned for utilities emphasize the costs of rooftop solar, while those by solar companies emphasize the benefits, and both depend on the extent to which a range of variables - avoided energy costs, generation capacity, transmission and distribution impacts, environmental benefits, and economic development - are included (Pitt and Michaud 2015).

In addition to contesting how the distributive implications of rooftop solar were calculated in the VOS preceding, rooftop solar advocates reframed the cost shift narrative as subjective and contingent. This generally took one of two forms. First advocates often claimed that there are many cost shifts in Tucson's electricity system, making the utility's focus on rooftop solar subjective and political. A comment by the chair 
of the City-County joint energy commission is exemplary: "TEP loves to talk about cost shifts. How about talking about the cost shift of their pollution onto the healthcare industry and the insurance industry and just the quality of peoples' lives?" (2016-05-27). A second theme was to reframe the cost shift as contingent by pointing to efforts by other states to make the benefits of rooftop solar more accessible to low-income ratepayers. For example, in 2006 the California Legislature passed Assembly Bill 2723 requiring the state's PUC to allocate money from the ratepayer-funded state solar initiative specifically for solar PV installations on low-income households. As a utility customer asked at the hearing:

So why can't Arizona and TEP and this Commission do what a number of other states have done and earmark low-income solar programs? Instead of scrambling to try to pay their bills as you heard many people talk about, we would be helping people get solar in their house so their bills would be reduced. (2016-08-31)

By emphasizing the possibility to allow low-income households to benefit from solar, participants reframed the cost shift narrative as contingent on a lack of efforts by TEP and the ACC to make DG solar accessible, rather than a necessary result of the technology and billing mechanisms. Rooftop solar advocates therefore advanced competing justice claims that challenged TEP's narrative on its own terms, and attempted to reframe the cost shift argument as subjective and contingent. Urban political ecology helps identify these competing understandings of distributive justice by understanding Tucson's electric grid as more than just a collection of wires, generators, substations, and inverters. Rather, UPE sees grid-tied solar panels as part of a produced socio-natural entity that reflects and reinforces configurations of political power (Swyngedouw and Heynen 2013; Silver 2016). While an apolitical analysis might accept the utility company's dominant justice narrative as given, UPE analyzes this narrative in a specific historical, political-economic, and material context. While the ACC ultimately approved a VOS tariff consistent with TEP's analysis, reframing rewiring as political and adopting a contextual analysis helps us see the cost shift as a strategic narrative rather than an objective distributive justice claim. This turns our attention to power in the decision-making processes that value rooftop solar and determine its distributive impact.

\section{Procedural justice: public participation and electricity governance}

Procedural justice requires equitable access to the decision making processes that govern distribution, in this case the TEP rate case and related processes like the ACC election. This type of justice moves attention from the cost shift narrative and competing distributive justice claims to questions about public participation, mechanisms of inclusion, information disclosure, and institutional representation (Jenkins et al. 2016). Rooftop solar advocates made two types of procedural justice claims. The first emphasized political economy and power relations to argue that the TEP rate case and Arizona utility regulation more broadly are structured to favor the interests of utility shareholders over ratepayers. However, a second narrative suggests that rooftop solar creates possibilities for greater procedural justice by assembling publics more engaged with electricity governance.

When TEP first met with Tucson officials, they brought a memo. As Brian Cohen recalled, the memo explained that "when there is more distributed generation installed in the utility's service area, revenue for the City goes down" (2016-06-10). Tucson receives a 2.25\% franchise tax from TEP so that when less electricity is sold the City gets less tax revenue (City of Tucson 2017). "Clearly that's not good for us", Cohen explained. "Even though our energy costs will go up, our revenue will go up even more. TEP had a number. This is how much money we were going to make with the new rates, and how much we would lose if we support solar." However, he added that the City balances its financial interests as a municipal corporation with its role as representative of its constituents. "Plan Tucson is unequivocal," he said, referring to the City's 2013 planning document developed through a multi-year public engagement process (Elias et al. 2013). "Tucsonans say we want solar. So we say to TEP, with that hat on, that's the other way we're invested in these rate cases." 
However, the City did not intervene in the TEP rate case and many interviewees connected this decision with the municipal franchise tax that ties the City's revenues to TEP's revenues. The franchise agreement provided just over 3\% (US\$14,699,330) of the city's General Fund budget in 2016 (City of Tucson 2017). As Cohen's description of TEP's memo suggests, the franchise agreement structures political-economic relations in ways that discouraged the City from intervening and representing its constituents in the utility's rate case. This point is emphasized by contrasting the City's decision not to intervene with Pima County's intervention and adamant opposition to all three of TEP's rate proposals related to rooftop solar (Huckelberry 2016). Unlike the City, Pima County does not receive a tax on utility revenues. The Tucson Mayor and City Council (2016) eventually passed a resolution opposing the TEP rate case, but only after substantial pressure from the Tucson-Pima County Metropolitan Energy Commission, a citizen advisory board. By not intervening in the rate case, the City did not participate in debates or give official testimony in the process that determined the ACC's decision. Procedural injustice therefore emerges from the City's failure to represent Tucson residents' desire for more solar energy, as identified through a multi-year public engagement process (Elias et al. 2013).

Rooftop solar advocates commonly identified two other examples of procedural injustice that, similar to the franchise tax, prioritized shareholder returns over ratepayer values in the processes that govern rooftop solar. First, interviewees noted that TEP's rate proposal and cost shift argument mirror model legislation from the conservative advocacy organization the American Legislative Exchange Council (ALEC). While ALEC self-identifies as a policy aid for state legislators, the organization receives funding from the investor-owned utility trade association the Edison Electric Institute, as well from ExxonMobil, Chevron, Peabody Energy, American Electric Power, and Duke Energy. ALEC has been described by the New York Times as a "stealth business lobbyist" (Cross, Weissman and Fanshaw 2016). In 2014 ALEC released model legislation along with a report titled Reforming Net Metering: providing a bright and equitable future (ALEC 2014; Tanton 2014), which explains the rooftop solar cost shift using the same logic as TEP and other Arizona IOUs in their 2015 and 2016 Rate Cases: "Net metering policies permit distributed generators to avoid paying their share of these grid investments, leaving the costs to be paid by other electricity users.... Net metering, as currently implemented, is a regressive tax subsidizing the rich by picking the pockets of the poor" (Tanton, 2014: 1). In Tucson, rooftop solar advocates pointed to ALEC's model NEM reform legislation to suggest that the utility's rate case is founded on a proposal deceptively designed to benefit utility and fossil fuel industry shareholders. As an employee of a Tucson solar company put it, "The way centralized power works with the Koch Brothers and the Edison Electric Institute and the fossil fuel interests as powerful as they are, this is a nationwide, centralized, coordinated campaign to put out partial and misleading information about net metering" (2016-06-09).

A third claim to procedural injustice emphasized undue utility influence in ACC elections. As a member of the Tucson-Pima County Metropolitan Energy Commission summarized:

There's a real issue in Arizona with dark money going into Corporation Commission campaigns. It's generally considered that at least three of the commissioners are heavily influenced by Arizona Public Service. As long as they have that ability to do regulatory capture, it's not exactly the regulators telling the utilities what they ought to be doing, it's more the other way around. (2016-05-27)

This refrain was common among rooftop solar advocates. A candidate in the 2016 ACC election explained how one need not prove the existence of corruption to acknowledge the effect of its implication: "The utilities have corrupted the ACC, if not overtly the appearance of corruption is there, and if by no other reason totally intimidated every politician in the state of Arizona with dark money campaigns" (2017-08-03). Debates about net metering and rooftop solar have become increasingly central to ACC politics since 2011, when two prosolar Democrats lost their seats to a now all-Republican Commission. It is widely acknowledged that APS spent US\$3.2 million to influence the ACC elections in 2014, and rooftop solar advocates claim that utility "dark money" calls into question the independence and ethics of state regulators (Brown 2016). Using the 
municipal franchise tax, ALEC's model legislation, and dark money in ACC elections as examples, rooftop solar advocates argued that electricity regulation is structured to give utility disproportionate political and economic power in decision making. However, this claim to procedural injustice was coupled by a second narrative suggesting that rooftop solar creates possibilities for greater procedural justice by assembling publics more engaged with electricity governance.

This second procedural justice narrative most often revolved around the idea that rooftop solar creates a public more informed and aware of electricity infrastructure and governance. A local solar installer captured this concept with the neologism "solaridarity", saying "I consider myself a solar soldier in 'solaridarity' with the Sonoran Desert community, to stand up for solar power to the people" (2016-08-31). He went on to explain how the utility's proposal would put an end to many jobs, like his own, which allow "green collar" laborers meaningful work that addresses the climate crisis and builds community. "Solar has been satisfying to my soul. 'Solaridarity' has motivated me to connect much more with our wonderful public community that has helped our grassroots movement blossom in addressing climate calamity and taking advantage of our abundant sunshine."

A different solar sales associate expanded on 'solaridarity' by explaining a process where individuals who install solar on their home become more politically engaged:

I think solar is empowering at so many levels. It empowers you to be more aware of your consumption and usage. Every solar system comes with monitoring software, so you can become a more active participant in your energy usage and become more informed at that level. And when you become your own energy producer, obviously you become more aware of how you're being billed and it's not just a rote activity. You're inherently more engaged. So I think there's a tremendous dialectic. And going out from there, if you take it to the next step and you see your own home or your system being meddled with by these outside forces that don't have your best interest at heart, then certainly you get more involved. (2016-06-09)

The narrative of 'solaridarity' connected rooftop solar to public participation in the TEP rate case and ACC elections. A candidate in the 2016 ACC election noted how the decision by electric utilities state-wide to coordinate their rate cases around NEM reform had the unintended consequence of raising public awareness of the commission.

Given the fact that they've all applied for a rate case this year, all of a sudden people who pay their utility bill know what the Corporation Commission does. So that raises an awareness by the public about our race." (2016-08-03)

As another interviewee noted, "the amount of civic engagement in this rate case is unprecedented" (2016-0609). This public participation is reflected in consumer comments filed in the 2016 TEP and UES rate cases, as compared to previous rate cases (Figure 1). Through participant observation, we also noticed that the ACC was repeatedly unprepared for the number of participants who attended public hearings. The Commission's largest hearing rooms were repeatedly filled to capacity, crowded halls were cleared to adhere to fire evacuation codes, and overflow screening rooms were hastily assembled so that participants could observe via projectors (Figure 2).

Though sometimes implicit, the possibility for distributed solar electricity production is always central to these suggestions that rooftop solar enhances procedural justice by enabling new forms of public participation. This draws attention to the unique material properties of PV solar technology, which allow for a large number of electric utility customers to become energy producers for the first time. The 'solaridarity' narrative is therefore linked to the materiality of rooftop solar, which facilitates a new role for utility customers as both consumer and producer of electricity (Gailing and Moss 2016). We expand on this connection in the conclusion. 


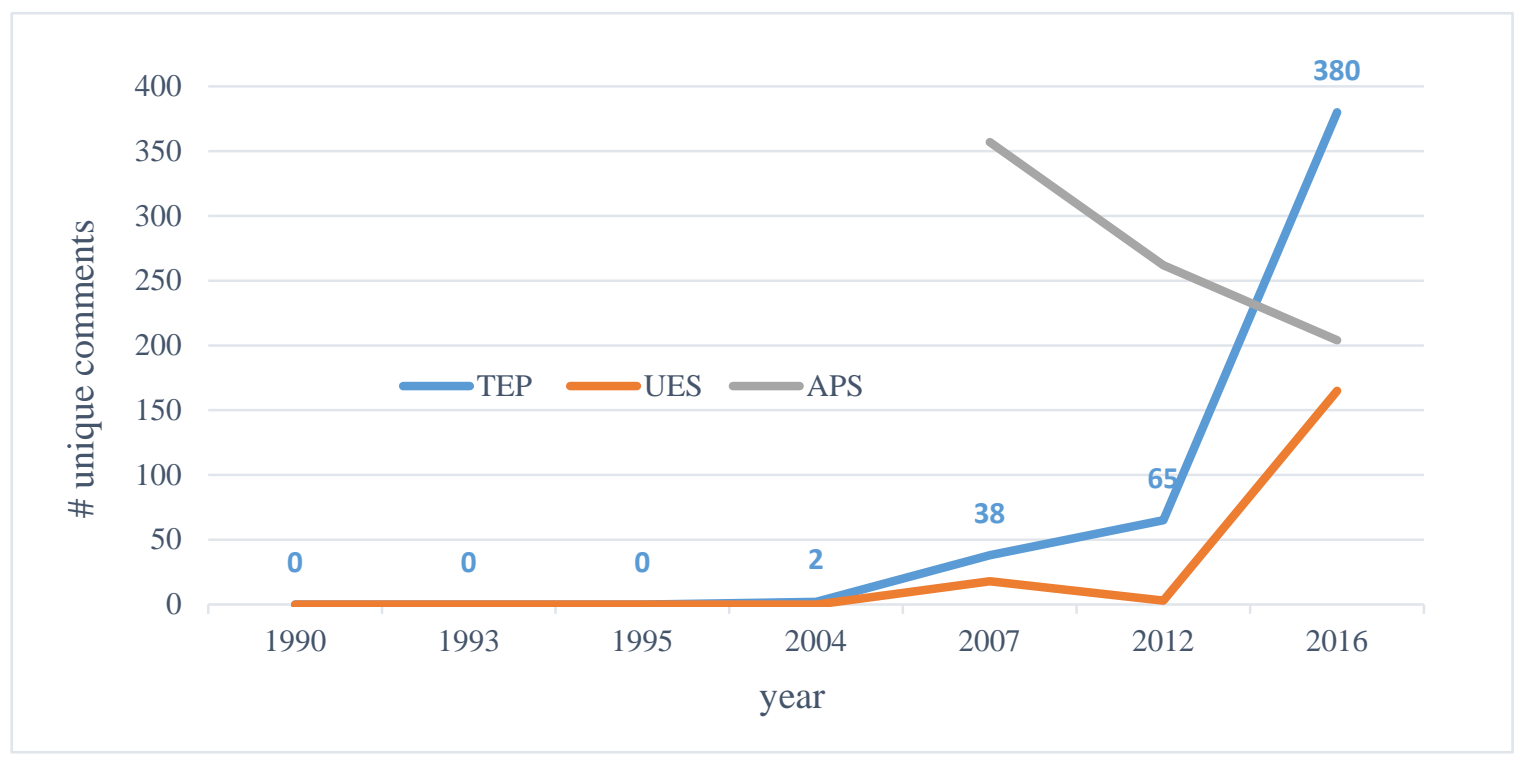

Figure 1: Number of consumer comments by year in three AZ investor-owned utility rate cases. Source: Remy Franklin. ${ }^{6}$

\section{Recognition justice: whose values?}

Energy justice scholars often draw on Young (1990) and Fraser (1997), as well as on subsequent interpretations (Schlosberg 2004; Walker 2009), to define recognition injustice as the processes of disrespect, misrecognition, non-recognition, and cultural and political domination that degrade and devalue some people and identities over others (Jenkins et al. 2016; McCauley et al. 2013). An example of non-recognition applied to energy is UK policymakers' long-time failure to recognize the needs of the elderly for higher-than-average room temperatures, which makes this social group more vulnerable to fuel poverty than other electricity users. Misrecognition and disrespect are also evident when developers and investors categorize local opponents to wind farms as selfish, conservative, and ignorant (Jenkins et al. 2016). While similar dynamics played out in the TEP rate case, we invoke recognition in a different but related sense that speaks to two questions: whose values and understandings of justice are recognized through electricity governance processes? Why did the utility's justice narrative prevail over those of rooftop solar advocates?

These questions allow for deeper analysis of the procedural justice narratives articulated by rooftop solar advocates. In the previous section, we presented a procedural justice narrative connecting rooftop solar and public participation in the TEP rate case. This was supported by the unusual number of consumer comments and a feeling by some that solar helps build a community more engaged with electricity production and governance. Implicit in this observation is the assumption that participation might promote justice through greater recognition of residential utility customers' values and interests, which are marginalized with respect to those of utility and fossil fuel industry shareholders.

\footnotetext{
${ }^{6}$ Includes comments filed as of February 24, 2017. Displays unique consumer comments for TEP rate cases and total consumer comment filings for APS and UES rate cases. Because the rate case eDockets include some consumer comment filings with multiple consumer comments, total filings and total unique comments are not equivalent. Unique comments were disaggregated for the TEP rate case because it is the primary focus of this article, while consumer comments in the UNS and APS dockets are simply counted as filings and included for the purpose of comparison. The authors note that comments did not increase in APS' most recent rate case. This may be because APS' rate case was in an earlier stage than the TEP and UES rate cases at the time of data collection.
} 


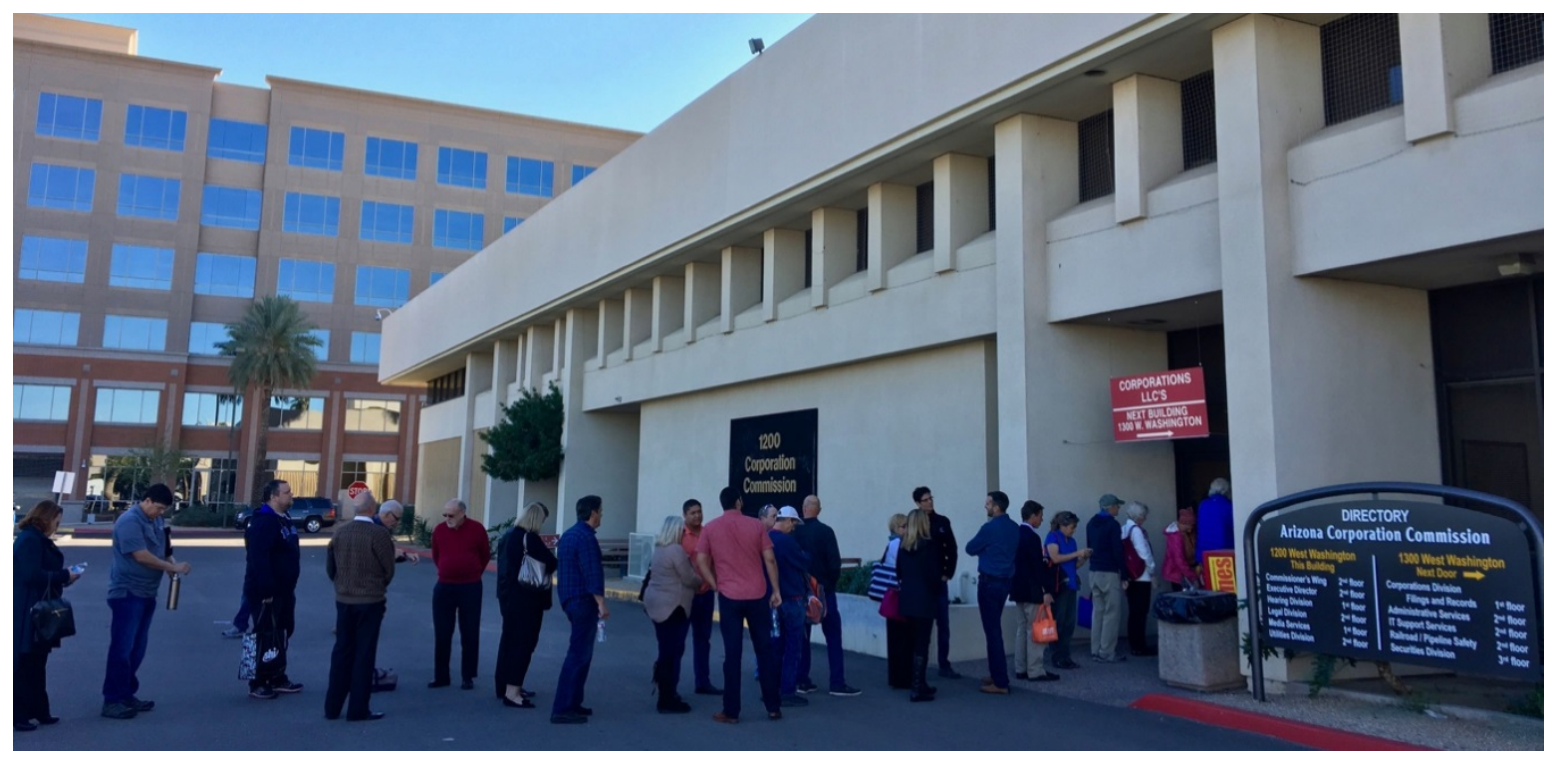

Figure 2: Participants wait to be admitted to the Value of Solar Public Hearing at the ACC's main Office in Phoenix Source: Remy Franklin 2016.

However, recognition raises the crucial questions of which utility customers are participating and what values they represent. Many residents do not have the capital or credit required to purchase or lease a solar system, and Arizona legislation excludes renters from participating in DG solar. These economic barriers to participating as a solar owner are combined with cultural barriers to engaging in decision-making processes. As time-consuming, highly formal and judicial processes, rate cases are likely to exclude portions of the population that are less educated and less comfortable providing public testimony in English in front of state regulators, all of whom in Arizona are white, Republican men. While no data is available that describes the demographics of rate case participants, 28.6\% of people in Pima County speak a language other than English at home (US Census, 2015). As one informant remarked on the hearings, "No one with limited English spoke, not once the entire night" (2016-08-31). While our data cannot rigorously speak to group identity and recognition, anecdotal evidence suggests that utility customers may be unequally represented at rate case hearings.

In addition to asking who is recognized among participating utility customers, the TEP rate case reveals a second, more systemic type of recognition injustice. In the previous section we analyzed narratives promoted by rooftop solar advocates to identify the municipal franchise tax, ALEC legislation, and regulatory capture as examples of procedural injustice. By emphasizing historical context, political economy, and materiality in these examples, UPE helps us see how non-recognition of residential utility ratepayers is embedded in the relations that structure electricity regulation. We therefore propose an additional understanding of recognition injustice as the systematic marginalization of values that are not shareholder value, which includes values of social and environmental justice expressed by rooftop solar advocates.

Central to this structural explanation of non-recognition is the utility business model based on rate of return regulation. As Pima County states in testimony filed in the TEP rate case, "rooftop solar is challenging the traditional utility business model" and "deeper systemic issues underlying TEP's filing need to be considered if the core problems (represented in ongoing re-occurring rate applications) are to be fully addressed and equitably resolved" (Huckelberry 2016). These deeper systemic issues include a financial model that incentivizes new utility-owned infrastructure projects, which justify increased costs and therefore revenues, followed by requests to modify rate structure to protect shareholders (Kind 2013; Laitner 2016). 
However, as declining demand and rapid deployment of DG resources have changed electricity markets, TEP now "seeks to shift the costs of its shortsighted planning to ratepayers (instead of shareholders) and to curtail the growth of emerging technologies through monopolizing the distribution of these resources" (Huckelberry 2016).

Individual rooftop solar advocates also claimed that TEP's business model structures decision making in ways that systematically ignore and devalue priorities other than shareholder returns. As a utility customer testified, "The reason they want to continue on in the model they have is that it's a cost-plus. It's not rational. It has nothing to do with the free market or anything really intelligent from a community perspective" (201608-31). In an interview, a former County employee said the utility's claims about a net metering cost shift is "just smoke to distract from the other 90 percent of what they're asking for," including a $12 \%$ return on investment and payment of the highest labor costs in the state (2016-08-02).

TEP's rate case can only be understood in the historical context of rate of return regulation and the material realities of electricity provision that made a regulated monopoly the only efficient way to provide widespread access to electricity services (Oppenheim 2016). However, the inadequacy of the traditional rate of return model for the current electricity landscape is widely acknowledged and critics have offered alternative incentive-based structures that could address many of the challenges rooftop solar poses to Arizona utilities (Lazar and Gonzalez 2015; Laitner 2016; New York State Department of Public Services 2017). The failure of the ACC to mandate new incentive structures is connected to concerns about utility company influence over state regulator elections, discussed as 'regulatory capture' in the previous section. Both TEP's business model and the failure of existing democratic avenues for changing it shape a political economy of electric utility ratemaking that favors shareholder values at the expense of claims to (in)justice put forward by rooftop solar advocates.

\section{Conclusion}

Drawing on urban political ecology to analyze claims that speak to distributive, procedural, and recognition (in)justice in the TEP rate case offers at least three insights that respond to our initial question: What are the implications of rooftop solar for energy justice? These insights follow the logical flow of the article to collectively suggest that a more accurate assessment of justice and rooftop solar requires refocusing our attention from distribution to process and recognition. They also reveal how distributive, procedural, and recognition justice are useful analytical categories but inseparable in politics and practice. In the case of rooftop solar, distributive justice is contingent on decisions made through a process, which also informs what values are recognized.

First, by recognizing competing justice claims that politicize TEP's cost shift argument, we reframed the cost shift as a strategic narrative. This reframing emphasizes that there are various and sometimes competing understandings of distributive justice, which can be deployed in strategic ways. It also shifts attention from the distributive justice question at the core of existing research about energy justice and rooftop solar - how does rooftop solar redistribute the costs of electricity through rates? - toward the processes that govern distribution. This refocusing is consistent with calls from environmental justice social movements and researchers who emphasize the importance of expanding beyond distribution to consider procedural and recognition justice (Fuller and Mccauley 2016; Schlosberg 2004; Walker 2009).

Our intention in making this modification is not to undervalue the importance of distributive justice or to claim that the utility's response to rooftop solar is necessarily wrong. Fair distribution of electricity's costs and benefits is the ultimate goal of energy justice and electric utilities like TEP are in many ways best positioned to orchestrate a just transition to an electricity system powered by renewable energy resources. However, our analysis of the TEP rate case suggests that the distributive implications of rooftop solar are contingent on value judgements decided through a highly contested process in which investor-owned utilities have disproportionate political and economic power.

This leads to a second insight related to the claim that rooftop solar creates possibilities for greater procedural justice by mobilizing residential utility customers to participate in electricity governance processes otherwise dominated by shareholder interests. Assessing this claim requires two logical steps. First, we 
showed that more utility customers participated in this TEP rate case than in previous years, and the concept of 'solaridarity' connects this participation to rooftop solar. It therefore seems that rooftop solar is assembling publics that are participating in electricity governance for the first time. To emphasize the agency of rooftop solar in this process, we propose a conceptualization of publics as socio-material collectives of humans and non-human actants co-produced and 'made public' through processes like the TEP rate case (Chilvers and Longhurst 2016; Clarke and Newman 2009). This draws attention to the unique material properties of rooftop solar, which unlike other technologies for electricity generation can be sited at a utility customer's residence. Participation by these newly-assembled publics might be understood as rooftop solar's tendency to counteract processes whereby urban infrastructure becomes 'black boxed' or normalized within spaces of consumption (Graham 2000).

However, wider participation says nothing of procedural justice necessarily, making the second part of this proposal best framed as a hypothesis for future research: rooftop solar promotes greater procedural justice via public participation that makes electricity governance more democratic. This hypothesis speaks directly to questions about the energy politics encouraged or enabled by particular types of infrastructure or sociomaterial configurations (Mitchell 2009). Our analysis suggests that new publics were assembled around rooftop solar, and for some this fostered a sense of civic engagement. While this participation brought new values and justice claims to the TEP rate case, the implications for distributive justice and democracy depend on who these publics represent and what values they promote. Addressing recognition (in)justice at the level of participating rooftop solar advocates is crucial, but beyond the scope of our empirical data. Future research should maintain a focus on recognition while asking what types of energy politics might be encouraged or enabled by rooftop solar as a relatively new socio-material configuration.

As a third insight we offer an explanation of how recognition injustice is (re)produced through debates about rooftop solar in the TEP rate case. By drawing on UPE to analyze narratives about rooftop solar and energy justice, we took a relational approach that understands the TEP rate case in a specific historical and material context. Our intention has been to show how specific examples of procedural injustice - the municipal franchise tax, ALEC's model legislation, and regulatory capture - are symptomatic of a business model that requires ongoing rounds of investment in utility-owned infrastructure. Rate of return regulation and the failure of existing democratic avenues to adjust incentives to a world of declining electricity demand perpetuate a ratemaking process that gives disproportionate power to utility shareholders over ratepayers. Competing understandings of a just electricity system - the narratives at the center of this article - were therefore judged through a process that systematically marginalizes the claims articulated by rooftop solar advocates. We suggest that this type of injustice can be usefully understood as the systemic non-recognition of values that are not shareholder value, including long-term social and environmental benefits and costs. Such a conceptual packaging requires that we move beyond the distributive focus of existing analysis to consider the implications of rooftop solar for procedural and recognition justice.

Finally, this more nuanced understanding of rooftop solar and energy justice indicates several concrete pathways toward a more just energy system in southern Arizona. TEP and the ACC could implement a lowincome solar program to ensure that utility customers most vulnerable to fuel poverty can benefit from solar investments and savings. Arizona legislation could be changed to support virtual NEM or a similar billing mechanism that makes residential and community solar accessible to customers without property suitable for a rooftop system (e.g. renters, apartment dwellers). Future rate cases could incorporate more deliberate public engagement processes including outreach to marginalized populations and less formal venues for participation. The value of solar tariff could be revised to incorporate a longer timeframe that captures social and environmental costs and benefits. Most importantly, the ACC could think beyond rate of return models to implement regulatory incentives that better align utility company profits with societal values. Taking any of these steps will ultimately require progressive state regulators, making the ACC elections a critical leverage point for tipping the balance of political power toward more just processes and outcomes. Efforts to lobby the City and utility company are likely to be less effective, although Tucson's 2025 renewal of TEP's franchise agreement will open possibilities for new politics.

At the time of writing, electric utility suppliers in most US states are determining the geographies of renewable energy in proceedings similar to the TEP rate case (Proudlove et al. 2017). New rates (re)produce 
socio-natural configurations of electricity infrastructure, making these proceedings a neglected focus for critical scholars and others interested in the justice dimensions of energy systems in transition. As this case study demonstrates, urban political ecology offers a useful approach for understanding energy justice by focusing on power, political economy, and the materiality of the electric grid. While this article offers initial insights about the implications of rooftop solar for energy justice in southern Arizona, the regional diversity of electricity infrastructure and institutions will require careful attention to the unique urban political ecologies of each case.

\section{References}

ACC 2014. Background and organization. Arizona Corporation Commission. [accessed 12 April 2017].

ALEC 2014. Updating Net Metering Policies Resolution. American Legislative Exchange Council. [accessed 12 April 2017].

Barrett, S. 2013. The necessity of a multiscalar analysis of climate justice. Progress in Human Geography 37(2): 215-233.

Bickerstaff, K., G. Walker and H. Bulkeley (eds.). 2013. Energy justice in a changing climate: social equity and low-carbon energy. London: Zed Books.

Bixler, R.P. 2013. The political ecology of local environmental narratives: power, knowledge, and mountain caribou conservation. Journal of Political Ecology 20: 273-285.

Blackburn, G., C. Magee and V. Rai. 2013. Solar valuation and the modern utility's expansion into distributed generation. The Electricity Journal 27(1): 18-32.

Bond, P. 2015. Can climate activists' 'movement below' transcend negotiators' 'paralysis above'? Journal of World-Systems Research 21(2): 250-270.

Bridge, G., S. Bouzarovski, M. Bradshaw and N. Eyre. 2013. Geographies of energy transition: space, place and the low-carbon economy. Energy Policy 53: 331-340.

Broto, V.C. and H. Bulkeley. 2013. Maintaining climate change experiments: urban political ecology and the everyday reconfiguration of urban infrastructure. International Journal of Urban and Regional Research 37(6): 1934-1948.

Brown, K.P. 2016. In the pocket: energy regulation, industry capture, and campaign spending. Sustainability: Science, Practice \& Policy 12(2).

Burnham, M., C. Radel, Z. Ma and A. Laudati. 2013. Extending a geographic lens towards climate justice, Part 1: climate change characterization and impacts. Geography Compass 7(3): 239-248.

Calvert, K. 2015. From 'energy geography' to 'energy geographies': perspectives on a fertile academic borderland. Progress in Human Geography 40(1): 1-21.

Chilvers, J. and N. Longhurst. 2016. Participation in transition(s): reconceiving public engagements in energy transitions as co-produced, emergent and diverse. Journal of Environmental Policy \& Planning (February): 1-23.

City of Tucson 2017. Adopted budget fiscal year 2017. [accessed 12 April 2017].

Clarke, J. and J. Newman. 2009. Publics, politics and power: Remaking the public in public service. London: Sage.

Cotty, S. 2015. Regional Greenhouse Gas Emissions Inventory 1990 - 2012. Pima Association of Governments. [accessed 12 April 2017].

Cross, R., G. Weissman and B. Fanshaw. 2016. Blocking the sun: utilities and fossil fuel interests that are undermining American solar power (2016 edition). Boston: Environment America Research and Policy Center.

Darghouth, N.R., R.H. Wiser, G. Barbose and A.D. Mills. 2016. Net metering and market feedback loops: exploring the impact of retail rate design on distributed PV deployment. Applied Energy 162: 713-722.

EIA 2016. Total electricity sales fell in 2015 for 5th time in past 8 years. U.S. Energy Information Administration. [accessed 12 April 2017]. 
Eid, C., J. Reneses, P. Frías and R. Hakvoort. 2014. The economic effect of electricity net-metering with solar PV: consequences for network cost recovery, cross subsidies and policy objectives. Energy Policy 75: 244-254.

Elias, A., N. Ewing-Gavin, A. Sanchez, R. Ruopp, G. Chorover, M. Gayosso, A. Vargas, A. Bertelsen, B. Flores, M. Berube, N. Ross, B. Gallivan and M. Voris. 2013. Plan Tucson: City of Tucson General \& sustainability plan 2013. [accessed 12 April 2017]. City of Tucson.

EPA 2017. Sources of Greenhouse Gas emissions. US Environmental Protection Agency. [accessed 15 April 2017].

Fainstein, S. 2010. The just city. Ithica, NY: Cornell University Press.

Forsyth, T. 2014. Climate justice is not just ice. Geoforum 54: 230-232.

Fraser, N. 1997. Justice interruptus: critical reflections on the 'postsocialist' condition. New York: Routledge.

Fuller, S. and D. Mccauley. 2016. Framing energy justice: perspectives from activism and advocacy. Energy Research and Social Science 11: 1-8.

Gailing, L. and T. Moss (eds). 2016. Conceptualizing Germany's energy transition: institutions, materiality, power, space. London: Palgrave Macmillan.

Hess, D.J. 2016. The politics of niche-regime conflicts: distributed solar energy in the United States. Environmental Innovation and Societal Transitions 19: 42-50.

Heynen, N. 2014. Urban political ecology I: the urban century. Progress in Human Geography 38(4): 598604. Academia

Heynen, N., M. Kaika and E. Swyngedouw (eds). 2006. In the nature of cities: urban political ecology and the politics of urban metabolism. London: Routledge.

Huber, M. 2015. Theorizing energy geographies. Geography Compass 9(6): 327-338.

Huckelberry, C. H. 2016. Pima County comments to the Arizona Corporation Commission: TEP rate case. Phoenix: Arizona Corporation Commission.

Jenkins, K., D. Mccauley, R. Heffron, H. Stephan and R. Rehner. 2016. Energy justice: a conceptual review. Energy Research \& Social Science 11: 174-182. draft

Jibilian, T. 2017. Opinion and order: in the matter of the Commission's investigation of value and cost of distributed generation. Phoenix: Arizona Corporation Commission.

Kaika, M. 2006. The political ecology of water scarcity: the 1989-1991 Athenian drought. In Heynen, N., M. Kaika and E. Swyngedouw (eds). In the nature of cities: urban political ecology and the politics of urban metabolism. London: Routledge. Pp. 150-164.

Keil, R. 2005. Progress report - urban political ecology. Urban Geography 26(7): 640-651. Researchgate

Kind, P. 2013. Disruptive challenges: financial implications and strategic responses to a changing retail electric business. Edison Electric Institute (January): 26.

Laitner, J.A. 2016. Comments of John A. 'Skip' Laitner, Ratepayers Expect New Economic Wisdom (RENEW). Phoenix: Arizona Corporation Commission.

Lazar, J. 2016. Electricity regulation in the US: a guide. Montpelier, VT. Regulatory Assistance Project.

Lazar, J. and W. Gonzalez. 2015. Smart rate design for a smart future. Regulatory Assistance Project.

Liverman, D. 2015. Reading climate change and climate governance as political ecologies. In Perreault, T., G. Bridge and J. McCarthy (eds.). Routledge handbook of political ecology. London: Routledge. Pp. 252253.

Loftus, A. 2006. The metabolic processes of capital accumulation in Durban's waterscape. In Heynen, N., M. Kaika, and E. Swyngedouw (eds.). In the nature of cities: urban political ecology and the politics of urban metabolism. London and New York: Routledge. Pp. 165-182.

Luque-Ayala, A. and J. Silver. 2016. Energy, power and protest on the urban grid: geographies of the electric city. New York: Routledge.

McCauley, D., R. Heffron, H. Stephan and K. Jenkins. 2013. Advancing energy justice: the triumvirate of 
tenets. International Energy Law Review 3: 107-110.

Mitchell, T. 2009. Carbon democracy. Economy and Society 38(3): 399-432.

New York State Department of Public Services 2017. Reforming the energy vision: about the initiative. [accessed 12 April 2017].

Nijbroek, R. 2014. Mangroves, mudbanks and seawalls: whose environmental knowledge counts when adapting to sea level rise in Suriname? Journal of Political Ecology 21: 533-550.

Oppenheim, J. 2016. The United States regulatory compact and energy poverty. Energy Research \& Social Science 18: 96-108.

Pitt, D. and G. Michaud. 2015. Assessing the value of distributed solar energy generation. Current Sustainability/Renewable Energy Reports 2: 105-113.

Preston, I., V. White, J. Thumim, T. Bridgeman and C. Brand. 2013. Distribution of carbon emissions in the UK: implications for domestic energy policy. York: Joseph Rowntree Foundation.

Procter, R. J. 2014. Fixed-cost recovery, renewables adoption and rate fairness. The Electricity Journal 27(5): 42-53.

Proudlove, A., B. Lips, D. Sarkisian and A. Shrestha. 2017. 50 states of solar: Q4 2016 quarterly report and annual review. NC Clean Energy Technology Center.

Rawls, J. 1971. A theory of justice. Cambridge: Belknap Press.

Rodda, J. L. 2017. Opinion and order: Tucson Electric Power Company (rates). Phoenix: Arizona Corporation Commission.

Schlosberg, D. 2004. Reconceiving environmental justice: global movements and political theories. Environmental Politics 13(3): 517-540.

Schlosberg, D. 2013. Theorising environmental justice: the expanding sphere of a discourse. Environmental Politics 22(1): 37-55.

Silver, J. 2016. Disrupted infrastructures: an urban political ecology of interrupted electricity in Accra. International Journal of Urban and Regional Research 39(5): 984-1003.

Sovacool, B.K. and M.H. Dworkin. 2015. Energy justice: conceptual insights and practical applications. Applied Energy 142: 435-444.

Sovacool, B.K., R.V. Sidortsov and B.R. Jones. 2014. Energy security, equality, and justice. London: Routledge.

Stockton, H. and R. Campbell. 2011. Time to reconsider UK energy and fuel poverty policies? York: Joseph Rowntree Foundation.

Swyngedouw, E. 1996. The city as a hybrid: on nature, society and cyborg urbanization. Capitalism, Nature, Socialism 7(2): 65-80.

Swyngedouw, E. and N.C. Heynen. 2003. Urban political ecology, justice and the politics of scale. Antipode 35(5): 898-918.

Tanton, T. 2014. Reforming net metering: providing a bright and equitable future. American Legislative Exchange Council.

TEP 2015. Application testimony and exhibits (volume 1 of 4). Tucson Electric Power. Phoenix: Arizona Corporation Commission.

TEP 2016a. 2016 Preliminary integrated resource plan. Tucson Electric Power. [accessed 12 April 2017].

TEP 2016b. New TEP program helps limited-income customers save with smart thermostats. Tucson Electric Power. 14 November. [accessed 12 April 2017].

TEP 2016c. Our history. Tucson Electric Power. [accessed 12 April 2017].

TEP 2017. New pricing plans, updated rates approved for TEP Customers. Tucson Electric Power. 8 February. [accessed 12 April 2017].

Trabish, H.K. 2016. Inside the deal that averted a net metering ballot showdown in Arizona. Utility Dive 3 March. [accessed 12 April 2017]. 
Tschakert, P. 2012. From impacts to embodied experiences: tracing political ecology in climate change research. Geografisk Tidsskrift-Danish Journal of Geography 112 (January): 37-41.

Tucson Mayor and City Council 2016. Resolution no. 22598: relating to utility rates; authorizing and approving the submission of comments in cases pending before the Arizona Corporation Commission; and declaring an emergency 6 July.

Walker, G. 2008. Decentralised systems and fuel poverty: are there any links or risks? Energy Policy 36, 4514-4517.

Walker, G. 2009. Beyond distribution and proximity: exploring the multiple spatialities of environmental justice. Antipode 41(4): 614-636.

Walton, R. 2017. Tucson Electric Power proposes lower rofotop solar incentive rates. Utility Dive 16 May. [accessed 17 July 2017].

Wichner, D. 2015. TEP seeks to raise customers' energy rates. Arizona Daily Star. 5 November. [accessed 12 April 2017].

Wichner, D. 2016a. TEP's new rate plans could cost more if customers fail to alter usage. Arizona Daily Star. 25 March. [accessed 12 April 2017].

Wichner, D. 2016b. TEP solar customers have months to benefit from net-metering rules. Arizona Daily Star 20 January. [accessed 12 April 2017].

Yamamoto, Y. 2012. Pricing electricity from residential photovoltaic systems: a comparison of feed-in tariffs, net metering, and net purchase and sale. Solar Energy 86(9): 2678-2685.

Young, I.M. 1990. Justice and the politics of difference. Princeton, NJ: Princeton University Press.

Zimmer, A. 2010. Urban political ecology: theoretical concepts, challenges, and suggested future directions. Erdkunde 64(4): 343-354. 